\title{
Peningkatan Kemampuan Berhitung Anak melalui Permainan Kartu Angka Pada Anak Kelompok B Di Tk Dharmawanita Pasar Usang
}

\author{
Yurda \\ Guru Taman Kanak-kanak \\ Email : yurda02@gmail.com
}

\begin{abstract}
Abstrak
Penelitian ini bertujuan untuk meningkatkan kemampuan berhitung melalui permainan kartu angka pada anak kelompok B1 TK Dharmawanita Pasar Usang. Jenis penelitian yang digunakan adalah penelitian tindakan kelas (PTK) yang dilakukan secara kolaboratif antara peneliti dan guru kelas. Penelitian ini terdiri dari 2 siklus yang setiap siklusnya dilakukan 2 kali pertemuan. Subjek penelitian ini adalah anak kelompok B1 yang berjumlah 24 orang anak. Objek penelitian adalah kemampuan berhitung. Teknik pengumpulan data melalui observasi dan wawancara. Instrumen yang digunakan adalah lembar observasi dan wawancara. Teknik analisis data dilakukan secara deskriptif kuantitatif. Hasil penelitian menunjukkan bahwa terdapat peningkatan kemampuan berhitung anak melalui permainan kartu angka. Hasil observasi pra tindakan menunjukkan bahwa anak yang berkriteria berkembang sesuai harapan hanya 7 orang atau $30 \%$. Pada siklus I meningkat menjadi 12 orang atau 50\%. Dan pada siklus II meningkat lagi menjadi 18 orang atau $75 \%$. Langkah-langkah yang ditempuh sehingga dapat meningkatkan kemampuan berhitung anak adalah guru mempersiapkan media yang menarik berupa kartu angka. Dengan demikian, dapat disimpulkan bahwa melalui permainan kartu angka dapat meningkatkan kemampuan berhitung anak pada kelompok $B$ TK Dharmawanita Pasar Usang.
\end{abstract}

Kata Kunci : Permainan Kartu Angka; Kemampuan Berhitung

\section{PENDAHULUAN}

Pendidikan Taman Kanak-kanak merupakan salah satu bentuk pendidikan anak usia dini. Pendidikan Taman Kanak-kanak memiliki peran yang sangat penting untuk mengembangkan kepribadian anak mempersiapkan mereka untuk memasuki jenjang pendidikan selanjutnya. Pendidikan Taman Kanak-kanak merupakan jembatan antara lingkungan keluarga dengan lingkungan lainnnya. Menurut Bihler dan Snowman (Hartati 
1996) pendidikan anak usia dini disediakan bagi anak usia dua setengah tahun samapi dengan enam tahun.

Salah satu bidang pengembangan ilmu yang sangat berguna bagi anak adalah pembelajaran matematika. Ada begitu banyak anak pada pendidikan dasar mengalami takut terhadap pembelajaran matematika. Pelajaran matematika sudah dianggap sebagai suatu pelajaran yang sangat sulit untuk dimengerti dan kurang disenangi. Rasa kurang senang atau takut yang tidak mendasar diawali karena situasi dan kondisi dalam belajar matematika pada pendidikan anak usia dini tidak diberikan dalam kondisi dan situasi yang menyenangkan sehingga dengan demikian guru sangat perlu untuk menciptakan situasi dan kondisi yang menyenangkan dalam mempelajari pelajaran matematika pada usia dini. Pada usia Taman Kanak-kanak, pengenalan berhitung permulaan sudah dapat dikenalkan kepada anak dengan menggunakan media yang mnarik bagi anak agar dapat menstimulus anak untuk menyukai pelajaran berhitung.

Kemampuan berhitung merupakan salah satu kemampuan dasar yang dikembangkan di Taman Kanak-kanak. Dasar-dasar kemampuan berhitung perlu dipersiapkan sejak usia dini agar kemampuan berfikir anak berkembang dengan baik. Anak-anak harus belajar memahami konsep bilangan, bentuk-bentuk angka sehingga anak mempunyai kesiapan untuk melanjutkan pada jenjang yang tinggi. Dasar-dasar kemampuan berhitung pada anak Taman Kanak-kanak dimulai dengan rasa ingin tahu anak terhadap angka dan bilangan.

Kemampuan berhitung seyogyanya dilatih dan dikembangkan sejak anak berada di Taman Kanak-kanak melalui permainan dan penggunaan metode yang tepat. Bermain merupakan sesuatu yang menyenangkan bagi anak, suasana yang menyenangkan dapat memicu kreatifitas dan menumbuhkan kemampuan, kemandirian, dan rasa percaya diri anak. Dengan demikian diharapkan potensi yang ada pada anak dapat berkembang secara optimal melalui aspek perkembangan anak yaitu menghitung atau menyebutkan urutan bilangan 1 sampai 20.

Kemampuan adalah suatu hal yang ingin dicapai seseorang dalam melakukan sesuatu. Menurut Conny (1990:1) mengemukakan bahwa kemampuan merupakan daya untuk suatu tindakan sebagai hasil dari pembawaan dan latihan. Ada tiga komponen penting yang tidak tampak dalam kemampuan diri manusia yaitu keterampilan, kemampuan dan etos kerja.

Spencer dalam Hamzah (2006:129) mendefinisikan kemampuan sebagai karakteristik yang menonjol dari seorang individu yang berhubungan dengan kinerja eektif dan atau superior dalam suatu pekerjaan atau situasi. Apabila membahas kemampuan, kita akan menghubungkan dengan istilah "potensi". Menurut Lubis dalam Gunarti 
(2008:1.29) potensi seorang anak merupakan anugrah Yang Maha kuasa. Individu tersebut berkembang, mengembangkan diri sehingga mampu menjalani kehidupan dimuka bumi ini. Ketika seorang anak manusia lahir, ia membawa segudang potensi, namun potensi tersebut harus didukung oleh orang dewasa yang ada disekitarnya.

kemampuan merupakan suatu kesanggupan atau kecakapan yang dimiliki seseorang mengerjakan sesuatu. Banyak sekali kemampuan yang harus diasah pada usia dini, salah satunya yaitu kemampuan berhitung. Kemampuan berhitung merupakan bagian dari pembelajaran matematika, dimana komponennya yaitu konsep bilangan dan lambang bilangan. Sebelum anak pandai berhitung, anak harus memahami terlebih dahulu konsep bilangan dan lambang bilangan.

Dalam kamus besar bahasa indonesia kemampuan adalah kesanggupan, kecakapan atau kekuatan. Kemampuan yang dimaksud dalam penelitian ini adalah kemampuan berhitung. Menurut suyanto (2005:73) mengemukakan bahwa berhitung merupakan dasar dari beberapa ilmu yang digunakan dalam kehidupan sehari-hari seperti penambahan, pengurangan, perkalian, dan pembagian. Untuk anak usia dini dalam konteks ini yaitu menghitung permulaan seperti menambah, mengurangi serta membandingkan.

Menurut Susanto (2011:98) berhitung permulaan adalah kemampuan yang dimiliki setiap anak untuk mengembangkan kemampuannya, karakteristik perkembangannya dimulai dari lingkungan yang terdekat dengan dirinya, perkembangan kemampuan anak dapat meningkat ketahap pengertian mengenai jumlah dan pengurangan. Sedangkan menurut depdiknas (2007:3) menjelaskan berhitung permulaan adalah suatu proses berfikir berupa kemampuan untuk menghubungkan, menilai dan mempertimbangkan sesuatu. Dapat juga dimaknai sebagai kemampuan memecahkan masalah atau untuk menciptakan karya yang dihargai dalam suatu kebudayaan.

Sejalan dengan itu, menurut pratiwi (2015) Berhitung adalah usaha melakukan, mengerjakan hitungan seperti menjumlah, mengurangi serta manipulasi bilangan-bilangan dan lambang-lambang matematika. Melalui berhitung anak lebih mampu mengembangkan aspek logika berpikir, terutama memaksimalkan fungsi belahan otak kirinya.

Dari beberapa pendapat diatas, dapat disimpulkan bahwa berhitung adalah kemampuan yang dimiliki oleh seseorang dalam matematika seperti kegiatan mengurutkan, penjumlahan, pengurangan, dan membilang.

Tujuan berhitung menurut Susanto (2011: 97) tujuan berhitung untuk anak usia dini adalah membekali anak untuk bekal kehidupannya di 
masa depan dengan memberikan bekal kemampuan berhitung anak. Depdiknas (2007:1) tujuan umum berhitung permulaan di Taman kanakkanak, untuk mengetahui dasar-dasar pembelajaran berhitung sehigga pada saatnya nanti anak akan lebih siap mengikuti pembelajaran berhitung pada jenjang selanjutnya yang lebih kompleks.

Menurut Susanto (2011:100) tahap bermain hitung anak usia didni, dengan megacu pada hasil penelitian Jean Piaget tentang intelektual, yang menyatakan bahawa anak usia 2-7 tahun berada pada tahap pra operasional, maka penguasaan kegiatan berhitung pada anak usia dini taman kanak-kanak akan melalui tahapp sebagai berikut:

1. Tahap konsep/pengertian

Tahap ini anak berekspresi untuk menghitung segala macam benda-benda yang dapat dihitung dan yang dapat dilihatnya.

2. Tahap transisi/peralihan

Tahap transisi merupakan masa peralihan dari konkret ke lambang, tahap ini ialah saat anak mulai benar-benar memahami benda yang dihitung dan bilangan yang disebutkan.

3. Tahap lambang

Tahap di mana anak sudah diberi kesempatan menulis sendiri tanpa paksaan, yakni berupa lambang bilangan, bentuk-bentuk dan sebagainya.

Kemampuan berhitung dapat dilatih melalui kegiatan bermain. Hal itu sesuai dengan kebutuhan anak akan bermain. Bermain merupakan kegiatan yang dilakukan untuk memperoleh kesenangan bagi anak. Kegiatan bermain tidak atas perintah siapapun, namun atas keinginan anak itu sendiri. Setiap hari, anak usia dini tidak lepas dari kegiatan bermain. Oleh karena itu, pembelajaran anak usia dini selalu dibuat atau dirancang dalam bentuk permainan agar secara tidak langsung melalui permainan tersebut anak menerima pendidikan.

Menurut yuliani dalam fadlillah (2017:7) menjelaskan mengenai pengertian bermain : (1) Menurut piaget bermain adalah suatu kegiatan yang dilakukan berulang-ulang dan menimbulkan kesenangan atau kepuasan bagi diri seseorang; (2) Menurut parten bermain adalah suatu kegiatan sebagai sarana bersosialisasi dan dapat memberikan kesempatan anak bereksplorasi, menemukan, mengekspresikan perasaan, berkreasi, dan belajar secara menyenangkan; (3) Menurut buhler dan danziger, bermain merupakan kegiatan yang menimbulkan kenikmatan; (4) Menurut docket dan fleer bermain merupaan kebutuhan bagi anak, karena melalui bermain anak akan memperoleh pengetahuan yang dapat mengembangkan kemampuan dirinya; (5) Menurut mayesty, bermain adalah kegiatan yang anak-anak lakukan sepanjang hari, karena bagi anak bermain adalah hidup dan hidup adalah permainan. 
Menurut fadlillah (2017:7) menyatakan bahwa bermain adalah suatu upaya untuk memperoleh kesenangan dan kepuasan jiwa dari setiap aktivitas yang dilakukan, baik menggunakan alat permaianan maupun tidak. Yang terpenting anak merasa gembira dengan permainan yang dilakukannya, serta tidak begitu memedulikan tentang hasil akhir yang akan didapatkan.

Menurut para ahli, bermain itu mengandung arti bagi kehidupan anak. Menurut Frobel dan Prianto (2003:48) bahwa bermain merupakan sarana untuk belajar. Dalam suasana bermain perhatian anak terhadap pelajaran dapat leih besar. Olehkarena itu, pelajaran yang diberikan akan lebih menarik dan menyenangkan hati anak sehinggahasilnya akan lebih baik.

Sejalan dengan itu, Mukhtar Latif (2013) menyatakan bahwa bermain diartikan sebagai suatu aktivitas yang langsung atau spontan, dimana seorang anak berinteraksi dengan orang lain, benda-benda disekitarnya, dilakukan dengan senang (gembira) atas inisiatif sendiri, menggunakan daya khayal (imajinatif) menggunakan pancaindra dan seluruh anggota tubuhnya. Dengan demikian, bermain merupakan kegiatan yang dilakukan secara spontan, menyenangkan tanpa memikirkan hasil akhir baik menggunakan alat permainan, maupun tidak.

Bermain memiliki peran penting dalam perkembangan anak pada hampir semua bidang perkembangan, baik perkembangan fisik-motorik, bahasa, intelektual, moral, sosial maupun emosional (slamet suyanto, 2015:124). Bermain dapat dilihat dari beberapa ciri, Menurut Rubin, Fein \& Vandenberg dalam fauziddin ada 5 ciri utama bermain : (1) Bermain didorong oleh motivasi dari dalam diri anak; (2) bermain dipilih secara bebas oleh anak; (3) bermain adalah suatu kegiatan yang menyenangkan; (4) bermain tidak selalu harus menggambarkan hal yang sebenarnya; (5) bermain senantiasa melibatkan peran ktif anak, baik secara fisik, psikologis, maupun keduanya sekaligus.

Sejalan dengan itu, Montolalu (2007) juga menyatakan pendapatnya mengenai karakteristik bermain anak : (1) bermain relatif bebas dari aturan-aturan, kecuali anak-anak membuat aturan mereka sendiri; (2) bermain dilakukan seakan-akan kegiatan itu dalam kehidupan nyata (bermain drama); (3) bermain lebih memfokuskan pada kegiatan atau perbuatan dari pada hasil akhir atau produknya; (4) bermain memerlukan interaksi dan keterlibatan anak-anak.

Bermain harus membuat rasa senang dan harus ada pendidikan . salah satu permainan yang mendidik dan dapat melatih kemampuan berhitung adalah permainan kartu angka. Kartu angka atau alat peraga kartu adalah alat-alat atau perlengkapan yang digunakan oleh seorang guru dalam mengajar yang berupa kartu dengan bertuliskan angka sesuai 
dengan tema yang diajarkan. Alat peraga kartu adalah alat bantu bagi anak untuk mengingat pelajaran. Alat peraga kartu huruf dapat menimbulkan kesan di hati sehingga anak-anak tidak mudah melupakannya. Sejalan dengan ingat anak akan alat peraga itu, ia juga diingatkan dengan pelajaran yang disampaikan guru. Semakin kecil anak, ia semakin perlu visualisasi/ konkret yang dapat disentuh, dilihat, dirasakan dan didengarnya (Nurani, 2012).

Alat peraga kartu adalah alat untuk menjelaskan yang sangat efektif, misalnya: untuk menjelaskan usia, ciri khas, karakter atau sifat dari seorang tokoh. Dengan alat peraga, gambar lebih jelas daripada dijelaskan dengan kata-kata saja. Sehingga anak dapat menghayati karakter tokoh yang diceritakan. Untuk menjelaskan situasi sebuah tempat, misalnya keadaan sebuah kota, bangunan dan sebagainya, dengan gambar akan lebih jelas daripada diceritakan secara lisan saja (Nurani, 2012).

\section{METODE PENELITIAN}

Penelitian ini menggunakan jenis-jenis penelitian tindakan kelas (PTK), Arikunto menyatakan bahwa Penelitian Tindakan Kelas adalah penelitian yang dilakukan oleh guru didalam kelasnya sendiri melalui refleksi diri, dengan tujuan untuk memperbaiki kinerjanya sebagai guru, sehingga hasil belajar anak menjadi meningkat.

Penelitian ini dilakukan di TK Dharmawanita Pasar Usang kecamatan Batang Anai Kabupaten Padang Pariaman kelompok B dengan jumlah anak 24 orang. Adapun waktu penelitian ini dilaksanakan selama 4 minggu di bulan Agustus 2019. Dalam penelitian ini menggunakan bagan alur arikunto, dilaksanakan dalam 4 tahapan yaitu perencanaan (planning), tindakan (acting), pengamatan (observasi) dan refleksi (reflecting).

Penelitian ini menggunakan instrumen lembar observasi aktivitas guru dan anak serta instrumen observasi anak dalam pengembangan kemampuan berhitung pada anak. Lembar observasi berbentuk check list berisi pedoman observasi yang berisikan daftar dari semua aspek yang akan diobservasi, sehingga observer tinggal memberi tanda ceklis tentang aspek yang diobservasi.

\section{HASIL}

Penelitian ini dilaksanakan di TK Dharmawanita Pasar Usang yang beralamat di Jl. Raya Padang Bukittinggi Kecamatan Batang Anai. TK Dharmawanita Pasar Usang saat ini berada di bawah kepemimpinan ibu 
Yurda, S.Pd, dan memiliki Sarana dan prasarana yang dimiiki TK Dharmawanita Pasar Usang berupa alat permainan outdoor dan indoor.

Subjek penelitian ini adalah anak kelompok B1 TK Dharmawanita Pasar Usang yang berjumlah 24 orang anak yang terdiri dari 10 anak lakilaki dan 14 anak perempuan. Berdasarkan hasil observasi pada bulan Juli 2019 di TK Dharmawanita Pasar Usang dapat diketahui bahwa kemampuan berhitung anak masih rendah. Kemampuan anak dalam berhitung melalui dokumentasi dan wawancara di dapat sebesar $30 \%$ atau 7 orang anak (Berkembang Sesuai Harapan), 50\% atau 12 orang anak (Mulai Berkembang) dan 20\% atau 5 orang anak (Belum Berkembang).

Tabel 1.

Persentase Hasil Penilaian Aktivitas Anak Pra Tindakan

\begin{tabular}{|l|l|c|c|}
\hline No & \multicolumn{1}{|c|}{ Kriteria } & Jumlah & Persentase \\
\hline 1 & BB (Belum Berkembang) & 5 & $20 \%$ \\
\hline 2 & MB( Mulai Berkembang ) & 12 & $50 \%$ \\
\hline 3 & BSH(Berkembang Sesuai Harapan) & 7 & $30 \%$ \\
\hline 4 & BSB (Berkembang Sangat Baik) & 0 & 0 \\
\hline
\end{tabular}

Kurangnya kemampuan berhitung pada anak dikarenakan pembelajaran yang dilakukan kurang menggunakan media yang menarik sehingga kemampuan berhitung anak kurang berkembang dan begitupun minat perhatian anak untuk belajar. Berdasarkan hasil refleksi dari pembelajaran pra tindakan maka peneliti pada kelompok B1 TK Dharmawanita Pasar Usang merancang tindakan untuk kegiatan pembelajaran pada siklus I yang dilakukan untuk meningkatkan kemampuan berhitung pada anak yaitu melalui permainan Kartu Angka.

\section{Siklus I}

Adapun hasil observasi dari perkembangan kemampuan berhitung anak siklus I ditampilkan dalam tabel sebagai berikut:

Tabel 2.

Hasil Observasi kemampuan berhitung anak Siklus I

\begin{tabular}{|c|c|c|c|c|c|c|}
\hline No & Nama & \multicolumn{2}{|c|}{ Persentase Penilaian } & Jumlah & $\begin{array}{c}\text { Rata- } \\
\text { rata }\end{array}$ & Kriteria \\
\cline { 3 - 6 } & & $\begin{array}{c}\text { Pertemuan } \\
\text { I }\end{array}$ & $\begin{array}{c}\text { Pertemuan } \\
\text { II }\end{array}$ & & & \\
\hline 1 & $\mathrm{Vr}$ & 41.66 & 50 & 91.66 & 45.83 & $\mathrm{MB}$ \\
\hline 2 & $\mathrm{Sf}$ & 50 & 58.33 & 108.33 & 54.16 & $\mathrm{BSH}$ \\
\hline 3 & $\mathrm{Cl}$ & 75 & 83.33 & 158.33 & 79.16 & $\mathrm{BSB}$ \\
\hline 4 & $\mathrm{Bd}$ & 41.66 & 66.66 & 108.32 & 54.16 & $\mathrm{BSH}$ \\
\hline 5 & $\mathrm{Fs}$ & 41.66 & 50 & 91.66 & 45.83 & $\mathrm{MB}$ \\
\hline 6 & $\mathrm{Fi}$ & 75 & 83.33 & 158.33 & 79.16 & $\mathrm{BSB}$ \\
\hline 7 & $\mathrm{Ry}$ & 41.66 & 50 & 91.66 & 45.83 & $\mathrm{MB}$ \\
\hline 8 & $\mathrm{Is}$ & 50 & 58.33 & 108.33 & 54.16 & $\mathrm{BSH}$ \\
\hline 9 & $\mathrm{Fr}$ & 66.66 & 75 & 141.66 & 70.83 & $\mathrm{BSH}$ \\
\hline
\end{tabular}




\begin{tabular}{|c|c|c|c|c|c|c|}
\hline 10 & $\mathrm{Zr}$ & 41.66 & 50 & 91.66 & 45.83 & $\mathrm{MB}$ \\
\hline 11 & $\mathrm{Sk}$ & 50 & 58.33 & 108.33 & 54.16 & $\mathrm{BSH}$ \\
\hline 12 & $\mathrm{Aw}$ & 33.33 & 41.66 & 74.99 & 37.49 & $\mathrm{MB}$ \\
\hline 13 & $\mathrm{Hb}$ & 75 & 83.33 & 158.33 & 79.16 & $\mathrm{BSB}$ \\
\hline 14 & $\mathrm{Ki}$ & 66.66 & 75 & 141.66 & 70.83 & $\mathrm{BSH}$ \\
\hline 15 & $\mathrm{Rz}$ & 41.66 & 66.66 & 108.33 & 54.16 & $\mathrm{BSH}$ \\
\hline 16 & $\mathrm{Ca}$ & 33.33 & 41.66 & 74.99 & 37.49 & $\mathrm{MB}$ \\
\hline 17 & $\mathrm{Ti}$ & 50 & 58.33 & 108.33 & 54.16 & $\mathrm{BSH}$ \\
\hline 18 & $\mathrm{Rt}$ & 50 & 58.33 & 108.33 & 54.16 & $\mathrm{BSH}$ \\
\hline 19 & $\mathrm{Bb}$ & 41.66 & 50 & 91.66 & 45.83 & $\mathrm{MB}$ \\
\hline 20 & $\mathrm{Ni}$ & 41.66 & 50 & 91.66 & 45.83 & $\mathrm{MB}$ \\
\hline 21 & $\mathrm{Zi}$ & 66.66 & 75 & 141.66 & 70.83 & $\mathrm{BSH}$ \\
\hline 22 & $\mathrm{Al}$ & 33.33 & 41.66 & 74.99 & 37.49 & $\mathrm{MB}$ \\
\hline 23 & $\mathrm{Yo}$ & 50 & 58.33 & 108.33 & 54.16 & $\mathrm{BSH}$ \\
\hline 24 & $\mathrm{Rf}$ & 66.66 & 75 & 141.66 & 70.83 & $\mathrm{BSH}$ \\
\hline
\end{tabular}

Dari tabel 2 dapat diketahui bahwa ketercapaian kemampuan berhitung anak pada siklus I menunjukkan kriteria anak belum berkembang tidak ada, mulai berkembang ada 9 orang anak, berkembang sesuai harapan ada 12 orang anak dan berkembang sangat baik ada 3 orang anak.

\section{Siklus II}

Adapun hasil observasi dari perkembangan kemampuan berhitung anak siklus I ditampilkan dalam tabel sebagai berikut.

Tabel 3.

Hasil Observasi kemampuan berhitung anak Siklus II

\begin{tabular}{|c|c|c|c|c|c|c|}
\hline No & $\begin{array}{c}\text { Nama } \\
\text { Anak }\end{array}$ & \begin{tabular}{c} 
Persentase Penilaian \\
\cline { 3 - 5 }
\end{tabular} & $\begin{array}{c}\text { Pertemuan } \\
\text { I }\end{array}$ & $\begin{array}{c}\text { Jertemuan } \\
\text { II }\end{array}$ & $\begin{array}{c}\text { Rata- } \\
\text { rata }\end{array}$ & Kriteria \\
\hline 1 & $\mathrm{Vr}$ & 58.33 & 66.66 & 124.99 & 62.49 & $\mathrm{BSH}$ \\
\hline 2 & $\mathrm{Sf}$ & 66.66 & 75 & 141.66 & 70.83 & $\mathrm{BSH}$ \\
\hline 3 & $\mathrm{Cl}$ & 83.33 & 91.66 & 174.99 & 87.49 & $\mathrm{BSB}$ \\
\hline 4 & $\mathrm{Bd}$ & 58.66 & 66.66 & 124.99 & 62.49 & $\mathrm{BSH}$ \\
\hline 5 & $\mathrm{Fs}$ & 58.66 & 66.66 & 124.99 & 62.49 & $\mathrm{BSH}$ \\
\hline 6 & $\mathrm{Fi}$ & 91.66 & 100 & 191.66 & 95.83 & $\mathrm{BSB}$ \\
\hline 7 & $\mathrm{Ry}$ & 58.33 & 66.66 & 124.99 & 62.49 & $\mathrm{BSH}$ \\
\hline 8 & $\mathrm{Is}$ & 66.66 & 75 & 141.66 & 70.83 & $\mathrm{BSH}$ \\
\hline 9 & $\mathrm{Fr}$ & 83.33 & 91.66 & 174.99 & 87.49 & $\mathrm{BSB}$ \\
\hline 10 & $\mathrm{Zr}$ & 58.33 & 66.66 & 124.99 & 62.49 & $\mathrm{BSH}$ \\
\hline 11 & $\mathrm{Sk}$ & 58.33 & 66.66 & 124.99 & 62.49 & $\mathrm{BSH}$ \\
\hline 12 & $\mathrm{Aw}$ & 83.33 & 91.66 & 174.99 & 87.49 & $\mathrm{BSB}$ \\
\hline 13 & $\mathrm{Hb}$ & 50 & 58.33 & 108.33 & 54.16 & $\mathrm{BSH}$ \\
\hline \multicolumn{7}{|c|}{}
\end{tabular}




\begin{tabular}{|c|c|c|c|c|c|c|}
\hline 14 & $\mathrm{Ki}$ & 83.33 & 91.66 & 174.99 & 87.49 & $\mathrm{BSB}$ \\
\hline 15 & $\mathrm{Rz}$ & 58.33 & 66.66 & 124.99 & 62.49 & $\mathrm{BSH}$ \\
\hline 16 & $\mathrm{Ca}$ & 50 & 58.33 & 108.33 & 54.16 & $\mathrm{BSH}$ \\
\hline 17 & $\mathrm{Ti}$ & 66.66 & 75 & 141.66 & 70.83 & $\mathrm{BSH}$ \\
\hline 18 & $\mathrm{Rt}$ & 58.33 & 66.66 & 124.99 & 62.49 & $\mathrm{BSH}$ \\
\hline 19 & $\mathrm{Bb}$ & 58.33 & 66.66 & 124.99 & 62.49 & $\mathrm{BSH}$ \\
\hline 20 & $\mathrm{Ni}$ & 58.33 & 66.66 & 124.99 & 62.49 & $\mathrm{BSH}$ \\
\hline 21 & $\mathrm{Zi}$ & 66.66 & 75 & 141.66 & 70.83 & $\mathrm{BSH}$ \\
\hline 22 & $\mathrm{Al}$ & 50 & 58.33 & 108.33 & 54.16 & $\mathrm{BSH}$ \\
\hline 23 & $\mathrm{Yo}$ & 66.66 & 75 & 141.66 & 70.83 & $\mathrm{BSH}$ \\
\hline 24 & $\mathrm{Rf}$ & 91.66 & 100 & 191.66 & 95.83 & $\mathrm{BSB}$ \\
\hline
\end{tabular}

Dari tabel 3 dapat diketahui bahwa ketercapaian kemampuan berhitung anak pada siklus II menunjukkan kriteria anak mulai berkembang tidak ada, ada 18 anak berkembang sesuai harapan, ada 6 anak berkembang sangat baik. Dari hasi data rekapitulasi siklus II di atas dapat diketahui bahwa kemampuan berhitung anak dari 24 anak yang menunjukkan krakteria anak mulai berkembang tidak ada, ada 18 anak (75\%) berkembang sesuai harapan, dan ada 6 anak (25\%) berkembang sangat baik. Dari data diatas dapat diketahui bahwa kemampuan berhitung anak sudah meningkat.

\section{PEMBAHASAN}

\section{Pra Tindakan dan Siklus I}

Berdasarkan hasil penelitian yang telah dilakukan dapat diketahui anak yang belum berkembang pada pra tindakan 5 orang anak $20 \%$ sedangkan pada siklus I tidak ada. Dengan terjadinya penurunan dari persentase tersebut disebabkan kerena anak telah mampu menyebutkan lambang bilangan 1-20, anak dapat mencocokkan bilangan dengan lambang bilangan, meskipun masih dibimbing oleh guru.

Penilaian anak dalam kategori mulai berkembang pada pra tindakan berjumlah 12 orang anak atau $50 \%$ sedangkan pada siklus I 9 orang anak atau $37,5 \%$ hal ini disebabkan karena anak telah bersemangat dan tertarik untuk mengikuti permaian kartu angka. Penilaian anak dalam kategori berkembang sesuai harapan pada pra tindakan berjumlah 7 orang anak atau $30 \%$ dan pada siklus I berjumalah 12 orang anak atau $50 \%$. Dengan terjadinya peningkatan ini disebabkan anak telah mencocokkan bilangan dengan lambang bilangan tanpa selalu diingatkan guru. Sedangkan penilaian pada anak berkembang sangat baik pada pra tindakan tidak ada dan pada siklus I berjumalah 3 orang anak atau $12,5 \%$. 


\section{Siklus I dan Siklus II}

Hasil penelitian pada siklus I dan siklus II menunjukkan bahwa adanya peningkatan kemampuan berhitung pada anak kelompok B TK Biana Asuhan Mayang Pongkai. Berdasarkan hasil penelitian yang dilakukan pada siklus I penilaian anak dalam kategori belum berkembang tidak ada dan pada siklus II juga tidak dan pada siklus II juga tidak ada,

Penilaian anak dalam kategori mulai berkembang pada siklus I ada 9 orang anak atau 37,5\%, pada siklus II tidak ada, hal ini disebabkan karena anak disebabkan kerena anak telah mampu menyebutkan lambang bilangan 1-20, anak dapat mencocokkan bilangan dengan lambang bilangan, meskipun masih di bimbing oleh guru.

Penilaian anak dalam kategori berkembang sesuai harapan pada siklus I berjumlah 12 orang anak atau 50\%, pada siklus II menjadi 18 orang anak atau 75\% Dengan terjadinya peningkatan ini disebabkan anak telah mencocokkan bilangan dengan lambang bilangan tanpa selalu diingatkan guru.

Sedangkan penilaian anak dalam kategori berkembang sangat baik pada siklus I berjumlah 3 orang anak atau 12,5\%, pada siklus II berjumlah 6 orang anak atau 25\% hal ini disebabkan karena anak disebabkan kerena anak telah mampu menyebutkan lambang bilangan 1-20, anak dapat mencocokkan bilangan dengan lambang bilangan, meskipun masih di bimbing oleh guru.

Berikut persentase peningkatan kemampuan berhitung anak pada tahapan pra tindakan, siklus I dan siklus II dapat dilihat pada tabel berikut:

Tabel 4.

Hasil Penilaian dalam Peningkatan Kemampuan Berhitung Anak Pra tindakan, Siklus I dan Siklus II

\begin{tabular}{|c|c|c|c|c|c|c|c|}
\hline No & Kriteria & \multicolumn{6}{|c|}{ Presentase Penilaian Anak } \\
\cline { 3 - 8 } & $\begin{array}{c}\text { Penilai } \\
\text { an }\end{array}$ & & \multicolumn{2}{|c|}{ Pra Tindakan } & \multicolumn{2}{c|}{ Siklus I } & \multicolumn{2}{c|}{ Siklus II } \\
\cline { 3 - 8 } & & $\begin{array}{c}\text { Jumlah } \\
\text { anak }\end{array}$ & $\begin{array}{c}\text { Persen } \\
\text { tase }\end{array}$ & $\begin{array}{c}\text { Jumlah } \\
\text { Anak }\end{array}$ & $\begin{array}{c}\text { Perse } \\
\text { ntase }\end{array}$ & $\begin{array}{c}\text { Jumlah } \\
\text { anak }\end{array}$ & $\begin{array}{c}\text { Perse } \\
\text { ntase }\end{array}$ \\
\hline 1 & BB & 5 & $20 \%$ & 0 & $0 \%$ & 0 & $0 \%$ \\
\hline 2 & MB & 12 & $50 \%$ & 9 & $37,5 \%$ & 0 & $0 \%$ \\
\hline 3 & BSH & 7 & $30 \%$ & 12 & $50 \%$ & 18 & $75 \%$ \\
\hline 4 & BSB & 0 & $0 \%$ & 3 & $12,5 \%$ & 6 & $25 \%$ \\
\hline
\end{tabular}

Untuk lebih jelasnya dapat dilihat dari gambar 4.4 


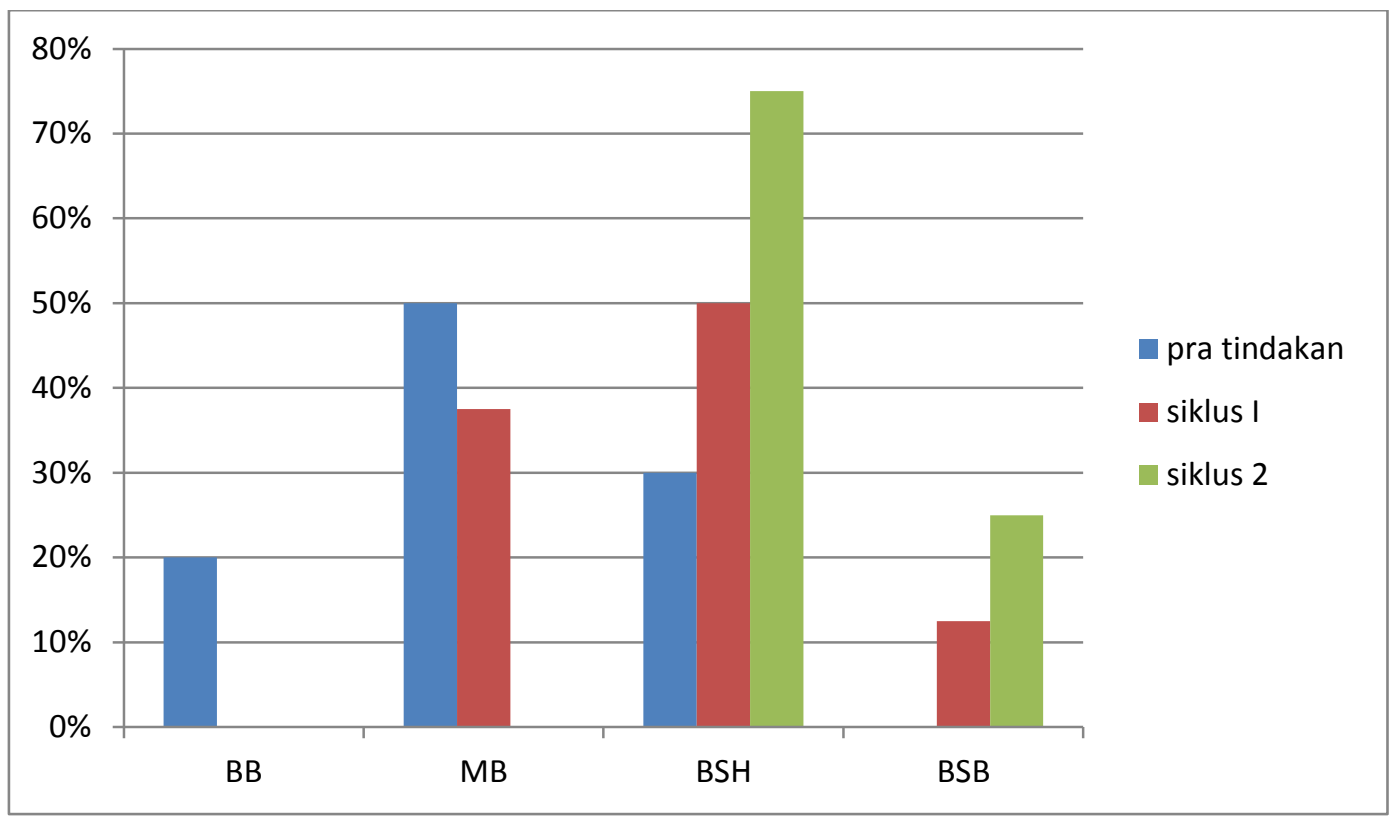

\section{Gambar 1 Hasil Penilaian dalam Peningkatan Kemampuan Berhitung Anak Pra tindakan, Siklus I dan Siklus II}

Setelah melihat hasil data kemampuan berhitung anak Kelompok B1 TK. Dharmawanita dalam peningkatan kemampuan berhitung anak pada grafik diatas dapat diketahui bahwa dengan menggunakan media permainan kartu angka dapat meningkatkan kemampuan berhitung anak. Hal ini dapat dilihat dari peningkatan persentase kemaampuan berhitung anak dengan menggunakan media permainan kartu angka.

Berdasarkan hasil observasi dan penelitian pada siklus I terlihat anak sudah mulai tertarik dalam mengikuti pembelajaran. Sebab pembelajaran tersebut dilakukan melalui kegiatan yang menyenangkan dan menarik membuat anak untuk terlibat aktif karna guru mengadakan tanya jawab dengan anak dalam mengikuti kegiatan.

Meningkatnya kemampuan berhitung melalui media permainan kartu angka diperkuat oleh teori Cahyo (2011) keunggulan media permain kartu angka antara lain: Menciptakan suasana pembelajaran yang fun, lebih merangsang anak dalam melakukan aktifitas belajar individual atau kelmpok, dapat mengembangkan kreatifitas kemandirian anak menciptakan komunikasi timbal balik serta dapat membawa tanggung jawab.

Pada siklus II menjadi semakin antusias dan terlibat aktif dalam permainan kartu angka, serta suasana kelas sudah semakain kondusif. Hal ini disebabkan anak tertarik untuk melihat kartu angka yang berwarnawarni, bagi anak yang mampu menyebutkan urutan 1-20 guru memberikan bintang begitu pun bagi anak yang bisa mencocokkan bilangan dengan lambang bilangan. Dengan demikian diberikan bintang tersebut dijadikan 
sebagai tambahan motivasi bagi setiap anak dalam menyelesaikan semua kegiatan.

Permainan kartu angka digunakan sebagai media belajar untuk anak, yang dapat meningkatkan kemampuan berhitung anak. Peningkataan kemampuan berhitung pada anak dapat dilihat dengan meningkatnya pemahaman anak pada saat anak menggunakan lambang bilangan untuk menghitung. Adapun indikator penilaian kemampuan berhitung anak dalam penelitian ini yaitu anak mampu menyebutkan urutan bilangan 1-20, anak dapat mencocokkan bilangan dengan lambang bilangan, anak mampu menggunakan lambang bilangan untuk menghitung.

Berdasarkan uraian di atas maka dapat dikatakan bahwa melalui media permainan kartu angka dapat meningkatkan kemampuan berhitung pada anak. Peningkatan tersebut terjadi karena melalui suatu permainan anak merasa lebih senang dan gembira, selain adanya media dan metode tersebut anak menjadi lebih semangat karena adanya penguatan dari guru. Setelah itu anak merasa senang karena pembelajaran menggunakan permaian kartu angka yang menarik serta metode pembelajaran yang bervariasi bagi anak.

\section{SIMPULAN}

Berdasarkan hasil penelitian dan pembahasan, maka dapat ditarik kesimpulan bahwa peningkatan kemampuan berhitung pada anak Kelompok B1 di TK Dharmawanita, pada semester ganjil 2019/2020, dapat ditingkatkan melalui kegiatan permainan kartu angka.

Peningkata tersebut dapat dilihat dari adanya penigkatan persentase dari tahap Pra Tindakan dan setelah dilakukan tindaakan kelas. Hasil observasi pada tahap Pra Tindakan anak yang berkembang sesuai harapan berjumlah 7 orang anak. Setelah dilakukan tindakan siklus I jumlah anak yang berkembang sesuai harapan berjumalah 12 orang anak atau 50\% dan pada Siklus II meningkat lebih baik lagi menjadi 18 anak atau $75 \%$.

Adapun faktor-faktor yang mempengaruhi peningkatan anak tersebut adalah:

1. Media yang digunakan dalam pembelajaran dapat menarik minat anak untuk mengikuti kegiatan berhitung

2. Penerapan permainan kartu angka dibutuhkan kerja sama antara peneliti, observer dan anak agar prosesnya berjalan sesuai harapan.

\section{DAFTAR PUSTAKA}

Ahmad Susanto. 2011. Perkembangan Anak Usia Dini. Jakarta: Kencana 
Alwi Hasan, dkk. 2009. Kamus Besar Bahasa Indonesia. Jakarta:

Depdikbud

Arikunto Suharsimi. 2010. Penelitian Tindakan Kelas. Jakarta : Bumi

Aksara

Conny R Semiawan. 2008. Psikologi Anak Usia Dini. Indeks: Jakarta

Depdiknas. 2009. Kurikulum Permen 58. Jakarta : Direktorat Pendidikan

Dasar

Fadlillah. 2017. Bermain dan Permainan. Jakarta: Kencana

Fauziddin Mohammad. 2015. Pembelajaran PAUD. Bandung:

Rosdakarya.

Gunarti. 2008. Orientasi Baru dalam Psikologi Pembelajaran. Jakarta: Bumi Aksara

Hamzah, B. Uno. 2006. Orientasi Baru dalam Psikologi Pembelajaran. Jakarta: Bumi Aksara

Montolalu. 2007. Bermain dan Permainan Anak. Universitas Terbuka: Jakarta

Nurani. 2012. Metode Pengembangan Kognitif. Jakarta: PT Indeks

Pratiwi Ema. 2015. Calistung Bagi Anak Usia Dini Antara Manfaat

Akademik dan Resiko Menghambat Kecerdasan Mental Anak.

Prosiding Seminar Nasional Pendidikan "Inovasi Pembelajaran

untuk Pendidikan Berkemajuan" FKIP Universitas Muhammadiyah

Ponorogo. 7 november 2015

Tadkirotun. 2012. Pengembangan Kecerdasan Majemuk. Tanggerang:

Universitas Terbuka. 